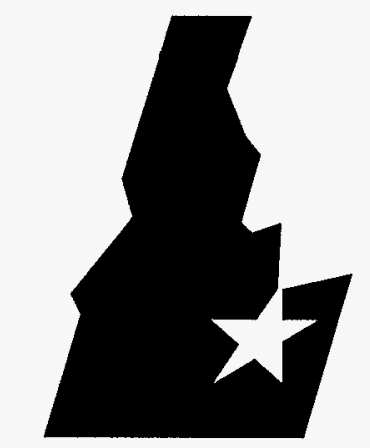

Idaho

National

Engineering

Laboratory
INEL-96/0370

September 1996

Idaho Chemical Processing Plant Low-Level Waste Grout Stabilization Development Program FY-96 Status Report

A. K. Herbst
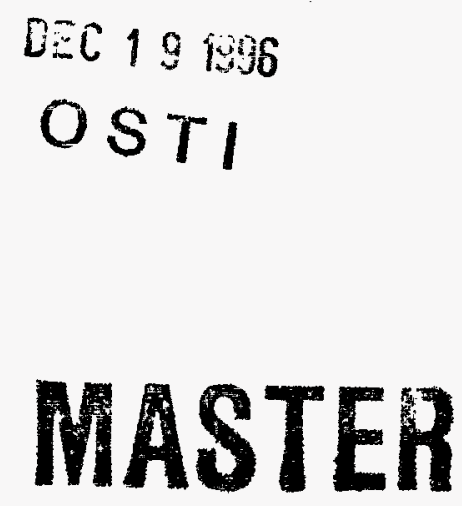

DISTRIBUTION OF THIS DOCUMENT IS UNLIMTIED MM

LOCKHEED MARTIN 


\title{
Idaho Chemical Processing Plant Low-Level Waste Grout Stabilization Development Program FY-96 Status Report
}

\author{
A. K. Herbst \\ Published September 1996 \\ Idaho National Engineering Laboratory \\ High Level Waste Program \\ Idaho Falls, Idaho 83415
}

Lockheed Martin Idaho Technologies Company

Prepared for the

U.S. Department of Energy

Assistant Secretary for Environmental Management

Under DOE Idaho Operations Office

Contract DE-AC07-941D13223 


\section{DISCLAIMER}

This report was prepared as an account of work sponsored by an agency of the United States Government. Neither the United States Government nor any agency thereof, nor any of their employees, makes any warranty, express or implied, or assumes any legal liability or responsibility for the accuracy, completeness, or usefulness of any information, apparatus, product, or process disclosed, or represents that its use would not infringe privately owned rights. Reference herein to any specific commercial product, process, or service by trade name, trademark, manufacturer, or otherwise does not necessarily constitute or imply its endorsement, recommendation, or favoring by the United States Government or any agency thereof. The views and opinions of authors expressed herein do not necessarily state or reflect those of the United States Government or any agency thereof. 


\section{DISCLAIMER}

Portions of this document may be illegible in electronic image products. Images are produced from the best available original document. 


\section{SUMMARY}

The general purpose of the Grout Stabilization Development Program is to solidify and stabilize the liquid low-level wastes (LLW) generated at the Idaho Chemical Processing Plant (ICPP). It is anticipated that LLW will be produced from the following: (1) chemical separation of the tank farm high-activity sodium-bearing waste; (2) retrieval, dissolution, and chemical separation of the aluminum, zirconium, and sodium calcines; (3) facility decontamination processes; and (4) process equipment waste. The main tasks completed this fiscal year as part of the program were chromium stabilization study for sodium-bearing waste and stabilization and solidification of LLW from aluminum and zirconium calcines.

The projected LLW will be highly acidic and contain high amounts of nitrates. Both of these are detrimental to Portland cement chemistry; thus, methods to precondition the LLW and to cure the grout were explored. A thermal calcination process, called denitration, was developed to solidify the waste and destroy the nitrates. Denitration reduces the waste volume and is over $99 \%$ effective in destroying the nitrates in the aluminum and zirconium LLW. For sodium-bearing LLW, denitration is $69 \%$ effective without additives and $97 \%$ effective when clay is combined with the waste. However, with clay addition, chromium leaches from the sodium-bearing LLW grout.

A three-way blend of Portland cement, blast furnace slag, and fly ash was successfully tested. Grout cubes were prepared at various waste loadings to maximize loading while meeting compressive strength and leach resistance requirements. For the sodium $L L W$, a $25 \%$ waste loading achieves a volume reduction of 3.5 and a compressive strength of 2500 pounds per square inch while meeting leach, mix, and flow requirements. It was found that the sulfur in the slag reduces the chromium leach rate below regulatory limits. For the aluminum LLW, a $15 \%$ waste loading achieves a volume reduction of 8.5 and a compressive strength of 4350 pounds per square inch while meeting leach requirements. Likewise for zirconium LLW, a $30 \%$ waste loading achieves a volume reduction of 8.3 and a compressive strength of 3570 pounds per square inch.

Continued waste form qualification is needed in the areas of compressive strength following sample immersion and thermal cycle testing. A grout pilot plant is planned for 2004 to test the equipment needed to concentrate, denitrate, and mix the grout and waste. Waste form qualification testing will be needed on fullscale disposal drums produced in the pilot plant. Testing is planned for low-level wastes derived from sodium-bearing calcine and decontamination and process equipment wastes. Additionally, the denitration process will be studied as to mass and energy balances and materials of construction. 



\section{CONTENTS}

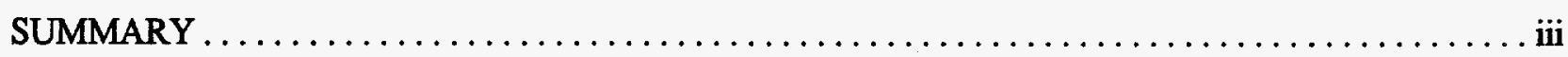

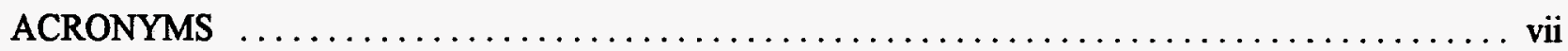

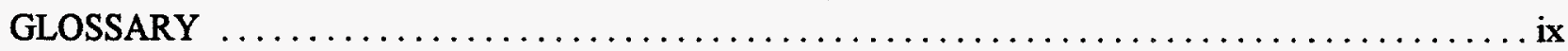

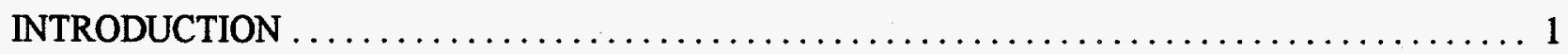

SIMULANT PREPARATION AND CONCENTRATION $\ldots \ldots \ldots \ldots \ldots \ldots \ldots \ldots \ldots \ldots \ldots$

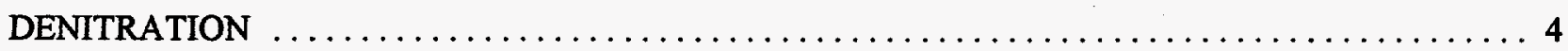

GROUT PREPARATION, CURING, AND COMPRESSIVE STRENGTH $\ldots \ldots \ldots \ldots \ldots \ldots \ldots \ldots$

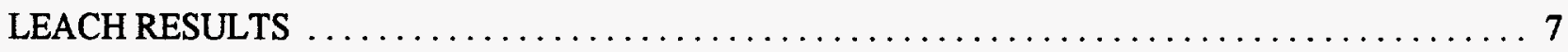

CONCLUSIONS AND RECOMMENDED FORMULATIONS $\ldots \ldots \ldots \ldots \ldots \ldots \ldots \ldots \ldots \ldots$

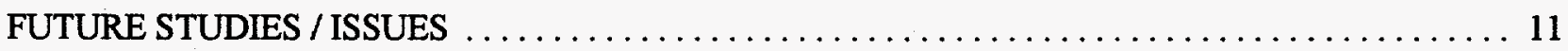

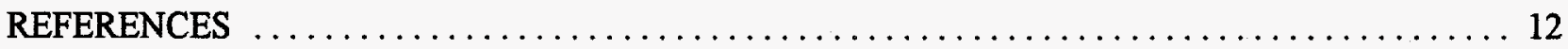

\section{FIGURES}

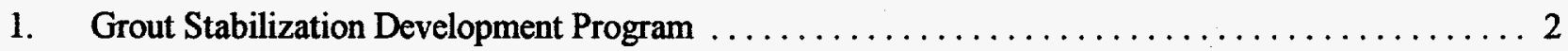

\section{TABLES}

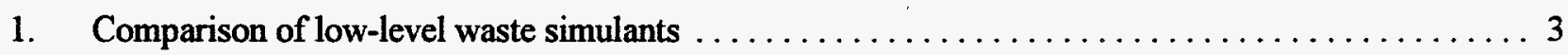

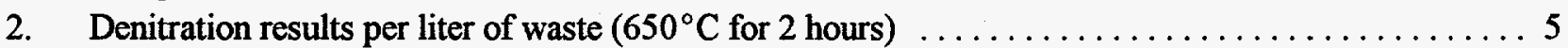

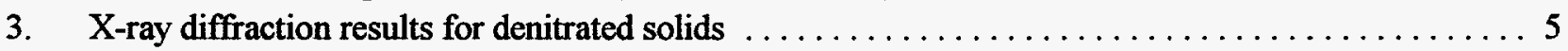

4. Grout density and compressive strength as a function of waste loading and curing method for sodium-bearing LLW denitrated without additives $\ldots \ldots \ldots \ldots \ldots \ldots \ldots \ldots \ldots \ldots$

5. Grout density and compressive strength as a function of waste loading and curing method for sodium-bearing $L L W$ denitrated with clay $\ldots \ldots \ldots \ldots \ldots \ldots \ldots \ldots \ldots \ldots \ldots$

6. Grout density and compressive strength as a function of waste loading and curing method

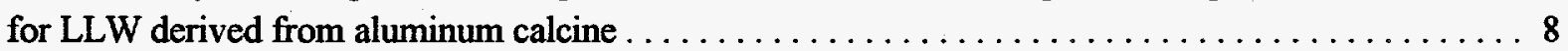

7. Grout density and compressive strength as a function of waste loading and curing method

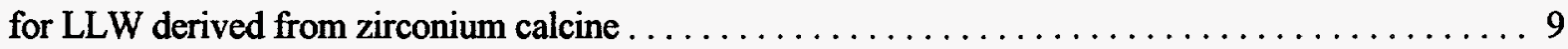

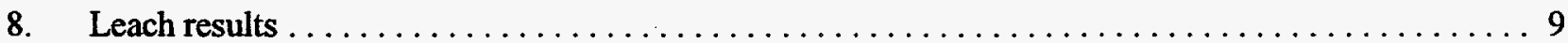





\section{ACRONYMS}

Al LLW

ASTM

CFR

Comp. Str.

DOE

ICPP

INEL

LLW

$\mathrm{Na}$ LLW

$\mathrm{No}_{\mathbf{x}}$

NRC

TCLP

Zr LLW
Low-level waste derived from aluminum calcine

American Society for Testing and Materials

Code of Federal Regulations

Compressive strength

U.S. Department of Energy

Idaho Chemical Processing Plant

Idaho National Engineering Laboratory

Low-level waste

Low-level waste derived from sodium-bearing waste

Oxides of Nitrogen

U.S. Nuclear Regulatory Commission

Toxicity Characteristic Leaching Procedure

Low-level waste derived from zirconium calcine 


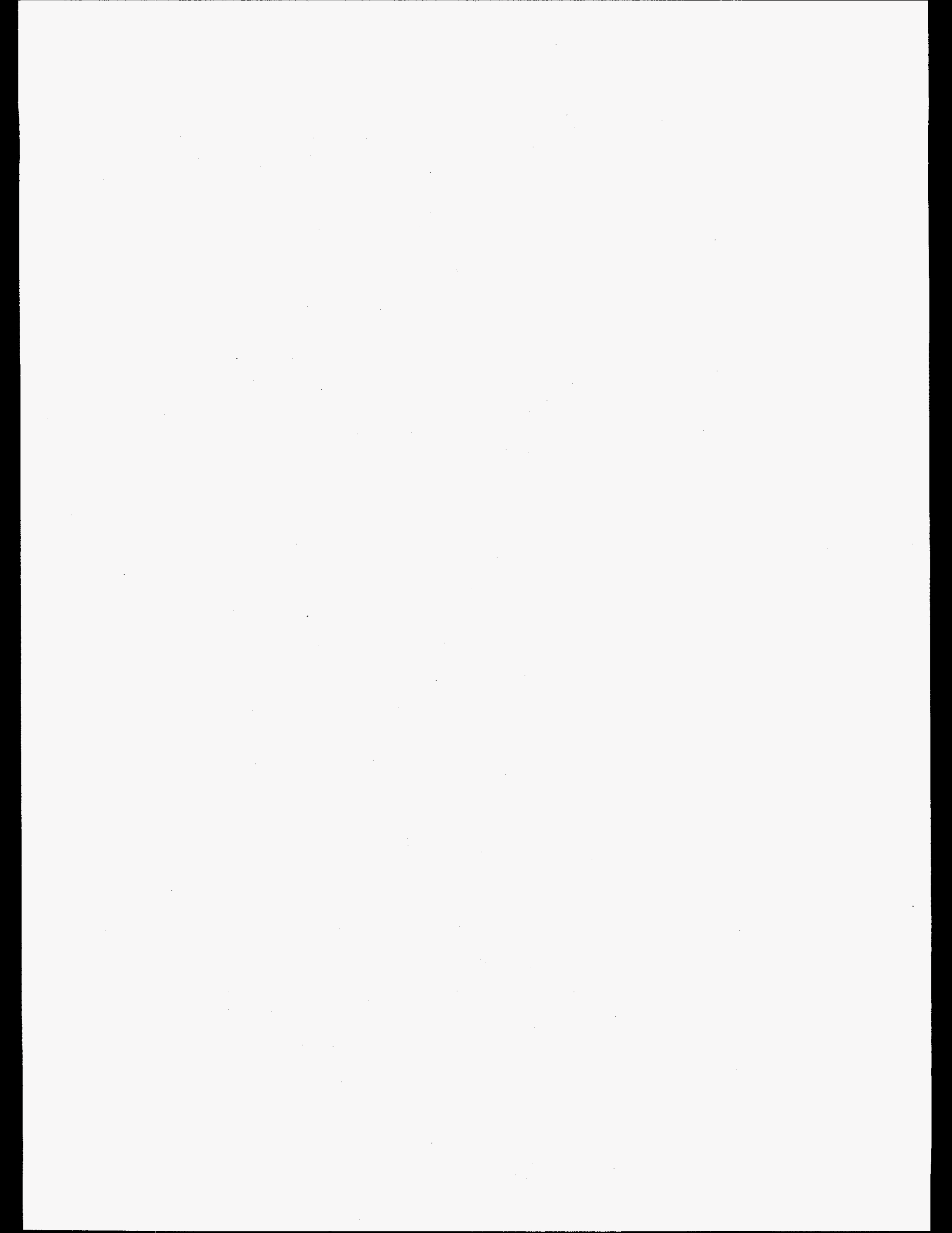




\section{GLOSSARY}

Calcination is the process of converting a liquid to a solid product called calcine.

\section{Cement refers to type I/II Portland cement.}

Fly Ash is a pozzolan of finely divided residue that results from the combustion of ground or powdered coal. Class C fly ash may contain $10 \%$ lime, has cementitious properties, and reacts with water to form a solid. Class $\mathrm{F}$ fly ash does not use water and aids in grout flow.

Grout is a mixture of Portland cement, other powdered additives, waste, and water. It may contain finegrained sand and does not include large aggregate material. For this study, grouting is the process of solidifying and stabilizing low-level waste in cement based materials.

Leaching is the process whereby a liquid agent will dissolve hazardous materials within a waste mass and transport these materials through the mass and beyond. The most widely used laboratory leaching test is the TCLP (Toxic Characteristic Leaching Procedure) specified by the EPA in several regulations. For many treated and untreated wastes, the results of this test determine whether the EPA considers the material toxic or not.*

Pozzolan is a siliceous or siliceous and aluminous material that reacts with liquid calcium hydroxide in the cement gel to form compounds possessing cementitious properties.

Solidification is the process of producing from liquid, sludge, or loose solids a more or less monolithic structure having some integrity. Occasionally, solidification may refer to the process that results in a soil-like material rather than a monolithic structure. Solidification does not necessarily reduce leaching of hazardous materials. However, when a waste is solidified, its mass and structure are altered, decreasing migration of solutions within the mass.*

Stabilization generally refers to a purposeful chemical reaction that has carried out to make waste constituents less leachable. This is accomplished by chemically immobilizing hazardous materials or reducing their solubility by a chemical reaction.*

Water-to-cement ratio is defined as the mass of the water divided by the mass of the cements used (Portland cement plus cement additives). In the case of the three way blends of Portland cement, blast furnace slag, and fly ash, the mass of the water was divided by the total mass of the three cementing agents. The mass of the waste is not included in this calculation.

Waste form is the final product for long-term storage. This includes the solidified/stabilized waste as well as the container. The waste form must pass extensive qualification testing prior to release for storage.

Waste loading is the mass of the waste on a dry basis that is added to the mass of the waste solidification/stabilization additives, also on a dry basis. The mass of the waste reflects only the amount of original waste placed in the final grout. The mass of preconditioning additives or off-gas products are not used in the calculation. 
Vitrify is the process of placing waste material in a glass form. This is a thermal process where the waste material is placed in a melter with glass beads or frit, then heated together, poured into a storage container, and cooled to a solid form.

Volume reduction factor is the original liquid low-level waste volume divided by the final grouted volume. A volume reduction factor of 2 would indicate the original waste volume grouted was twice the grouted volume. Thus, there would be less grouted waste than the original LLW. If the volume reduction factor is 0.25 , the grouted volume is 4 times larger than the original volume. An objective of the conditioning and grouting processes is to optimize (raise) the volume reduction factor; thus, reducing final repository costs based on volume.

* Definition taken directly from Reference 8. 


\title{
IDAHO CHEMICAL PROCESSING PLANT LOW-LEVEL WASTE GROUT STABILIZATION DEVELOPMENT PROGRAM FY-96 STATUS REPORT
}

\author{
INTRODUCTION
}

The High-Level Waste Program Plan calls for the calcine in the storage bins at the Idaho Chemical Processing Plant (ICPP) to be retrieved, dissolved in nitric acid, and separated into high-activity and lowlevel radioactive wastes. ${ }^{1,2}$ The sodium-bearing liquid waste in the tank farm may be directly separated or calcined and processed later. The small volume, high-activity waste will be vitrified and disposed of in a geological repository. The large volume, low-level waste (LLW) will be grouted and sent to a near-surface low-level disposal facility. In addition to the LLW derived from high-activity wastes, facility decontamination and the process equipment waste system will generate LLW.

The use of cements for grouting low-level nuclear waste is extensively documented in the literature and is in use in several countries. ${ }^{3-8}$ However, the liquid and calcine wastes at ICPP are unique in composition and do not match wastes stabilized at other facilities. The projected low-level wastes are acidic, high in nitrates, and may contain heavy metals and organics, as well as, radionuclides. All of these attributes can be detrimental to grout stability. Therefore, processing methods and grout formulations are needed to address these specific wastes. The overall development flowsheet is illustrated in Figure 1. Further details of the LLW grout program can be found in Section 4.5 of the High-Level Waste Program Plan. ${ }^{1}$

Optimal grout formulations should maximize waste loading, reduce waste volume, and produce a viable waste form. The waste form must be solid and restrict the leaching of radionuclides and hazardous metals. The Department of Energy (DOE) Order 5820.2a, "Radioactive Waste Management," does not contain specific waste form criteria. Therefore, the guiding document for this research is the "Technical Position on Waste Form," published by the Low-Level Waste Management Branch of the U.S. Nuclear Regulatory Commission. ${ }^{9}$ Waste form qualifications include compressive strength, leach resistance, thermal cycling, and immersion testing. Only compressive strength and leach resistance are addressed in this study. ${ }^{10}$

Studies on simulated sodium-bearing LLW show that the LLW must be preconditioned prior to grouting. A thermal calcination process, called denitration, heats the waste to $650^{\circ} \mathrm{C}$, volatilizes or decomposes the nitrates, and solidifies the waste. The solid can then be grouted with a three-way blend of Portland cement, blast furnace slag, and fly ash. These processes produce a solid waste form that passes compressive strength and leach resistance requirements at comparatively high waste loadings. Therefore, denitration and the blended grout are the basis for test grouting the projected types of LLW at ICPP.

A cooperative research and development agreement (CRADA) was established with S. M. Stoller Corporation (Boulder, Colorado) and Nuclear Fuel Industries, Limited (Osaka, Japan) to investigate waste stabilization using innovative ceramic materials called Thomas Ceramics and soil hardening agents called Fujibenton. The CRADA is still in place; however, no work on LLW simulants was done this fiscal year (FY). 


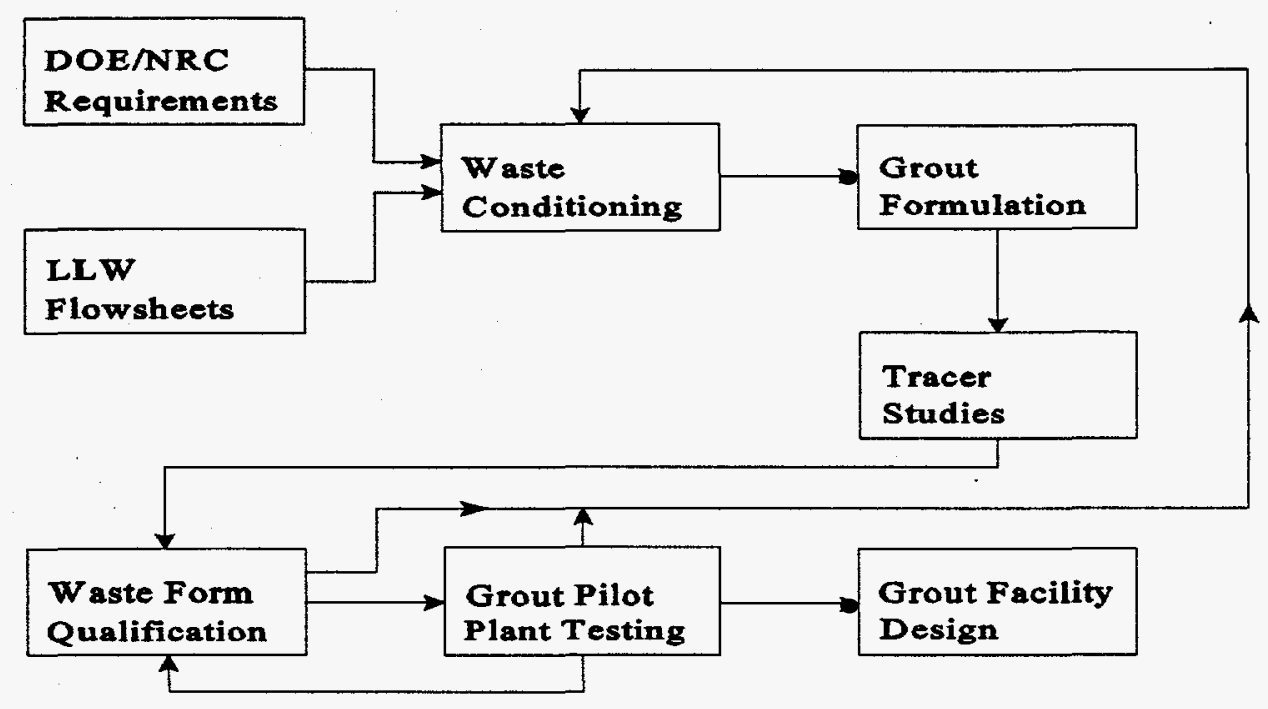

Figure 1. Grout Stabilization Development Program.

\section{SIMULANT PREPARATION AND CONCENTRATION}

The composition of sodium, aluminum, and zirconium simulated low-level wastes is shown in Table 1. In general, one liter of LLW has a mass of about 1100 grams, of which about 900 grams are acids and water and 200 grams are dissolved solids. The majority of the dissolved solids, 170 to 185 grams, is nitrates $\left(\mathrm{NO}_{3}\right)$. The sodium-bearing waste contains four hazardous heavy metals (cadmium, chromium, lead, and mercury) and is high in sodium and aluminum nitrates. The zirconium LLW contains cadmium, while the aluminum LLW does not contain any hazardous metals. All are highly acidic with a pH less than 1.

The LLW simulants can be concentrated by evaporation. The volume can be reduced to $30 \%$ with no problems. However, in one case with aluminum LLW, the volume was reduced to less than $10 \%$ at which time precipitates started to form. As the solution cooled, a white cake formed in the beaker which had the consistency of paraffin. Overnight the residue crystallized, expanded, and broke the beaker. Thus, in fullscale operations, the wastes should not be concentrated to a solid due to the possibility of vessel rupture.

The off-gas from the concentration process is extremely acidic. Thus, appropriate materials of construction will be needed for the off-gas piping, scrubbers, and filters. If the denitration process (discussed in the next section) can handle the excess liquids, then a separate concentration unit operation may not be needed. This will be studied during pilot-scale equipment testing. 
Table 1. Comparison of low-level waste simulants.

\begin{tabular}{|c|c|c|c|c|}
\hline Species & Stock Chemical & $\begin{array}{c}\mathrm{Na} L L W \\
(\mathrm{~g} / \mathrm{L})\end{array}$ & $\begin{array}{c}\text { Al LLW } \\
(\mathrm{g} / \mathrm{L})\end{array}$ & $\begin{array}{c}\mathrm{Zr} \text { LLW } \\
(\mathrm{g} / \mathrm{L})\end{array}$ \\
\hline $\mathrm{H}^{+}$ & All Acids & 0.78 & 1.59 & 1.62 \\
\hline $\mathrm{Al}$ & $2.2 \mathrm{M} \mathrm{Al}\left(\mathrm{NO}_{3}\right)_{3}$ & 9.09 & 10.41 & 4.86 \\
\hline B & $\mathrm{H}_{3} \mathrm{BO}_{3}$ & 0.10 & 0.04 & 0.38 \\
\hline $\mathrm{Cd}$ & $\mathrm{Cd}\left(\mathrm{NO}_{3}\right)_{2} \cdot 4 \mathrm{H}_{2} \mathrm{O}$ & 0.17 & - & 0.39 \\
\hline $\mathrm{Ca}$ & $\mathrm{Ca}\left(\mathrm{NO}_{3}\right)_{2}$ & 1.12 & - & 14.67 \\
\hline $\mathrm{Cl}$ & $12.0 \mathrm{M} \mathrm{HCl}$ & 0.54 & - & 一 \\
\hline $\mathrm{Cr}$ & $\mathrm{Cr}\left(\mathrm{NO}_{3}\right)_{3} \cdot 9 \mathrm{H}_{2} \mathrm{O}$ & 0.10 & - & - \\
\hline F & $27.6 \underline{\mathrm{M}} \mathrm{HF}$ & 0.69 & - & 10.75 \\
\hline $\mathrm{Fe}$ & $\mathrm{Fe}\left(\mathrm{NO}_{3}\right)_{3} \cdot 9 \mathrm{H}_{2} \mathrm{O}$ & 0.65 & 0.09 & 0.10 \\
\hline $\mathrm{Pb}$ & $\mathrm{Pb}\left(\mathrm{NO}_{3}\right)_{2}$ & 0.15 & - & - \\
\hline Mn & $\mathrm{Mn}\left(\mathrm{NO}_{3}\right)_{2}$ & 0.46 & 一 & 0.01 \\
\hline $\mathrm{Hg}$ & $\mathrm{Hg}\left(\mathrm{NO}_{3}\right)_{2} \cdot \mathrm{H}_{2} \mathrm{O}$ & 0.11 & - & 一 \\
\hline Mo & $\mathrm{H}_{2} \mathrm{MoO}_{4}$ & 0.04 & - & - \\
\hline $\mathrm{Ni}$ & $\mathrm{Ni}\left(\mathrm{NO}_{3}\right)_{2} \cdot 6 \mathrm{H}_{2} \mathrm{O}$ & 0.05 & - & - \\
\hline $\mathrm{NO}_{3}$ & $15.9 \underline{\mathrm{M}} \mathrm{HNO}_{3}$ & 184.73 & 174.30 & 170.62 \\
\hline $\mathrm{PO}_{4}$ & $14.8 \underline{\mathrm{M} \mathrm{H}_{3} \mathrm{PO}_{4}}$ & - & 一 & 0.05 \\
\hline $\mathrm{K}$ & $\mathrm{KNO}_{3}$ & 4.22 & - & 0.25 \\
\hline $\mathrm{Na}$ & $\mathrm{NaNO}_{3}$ & 25.33 & 2.08 & 2.72 \\
\hline $\mathrm{SO}_{4}$ & 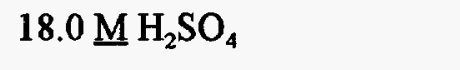 & 2.53 & 0.26 & 0.16 \\
\hline \multirow[t]{4}{*}{$\mathrm{Zr}$} & $\mathrm{ZrO}\left(\mathrm{NO}_{3}\right)_{2} \cdot 3 \mathrm{H}_{2} \mathrm{O}$ & 0.05 & - & 7.75 \\
\hline & Mass $=$ & 230.91 & 188.77 & 214.33 \\
\hline & Total $\mathrm{NO}_{3}=$ & 184.73 & 174.31 & 170.62 \\
\hline & Average Mass with $\mathrm{H}_{2} \mathrm{O}=$ & 1139.2 & 1108.4 & 1119.8 \\
\hline
\end{tabular}




\section{DENITRATION}

The projected low-level wastes are very acidic and contain high amounts of nitrates. Laboratory studies have shown that direct grouting is not effective in terms of volume reduction. For example, one cubic meter of waste becomes three cubic meters of grout. If the waste is concentrated prior to grouting to achieve higher waste loadings, the Portland cement fails to cure properly due to high concentrations of acid and nitrates. Therefore, it is desirable to solidify the waste and destroy the nitrates prior to grouting to achieve an effective volume reduction and stable grout. The process to destroy nitrates is called denitration, which is accomplished by thermally treating the low-level waste.

Two methods of thermal denitration are used the condition the LLW. The first method heats the waste without any additives and the second method heats a mixture of waste and clay. The clay is added with the intent to produce a zeolite mineral, sodium-aluminum silicate, which should be stable in the grout. ${ }^{11-13}$ Laboratory studies have found that the optimum temperature for solidification and nitrate destruction is $650^{\circ} \mathrm{C}$ for at least two hours. ${ }^{14}$

The laboratory denitration process is accomplished with a furnace and ceramic crucibles. About 50 to 100 milliliters of simulant are progressively added to the crucible, which is placed in the furnace at $650^{\circ} \mathrm{C}$ for 10 to 20 minutes until the liquid is solidified. Once all the liquid is solidified, the solids are left in the furnace for two hours. For the Na LLW, new liquid can be added on top of the solids. However, when adding liquid Al LLW or Zr LLW to the solids, the solids dissolve and the excess solution froths and spills over the crucible. This problem is overcome by removing the solids between liquid additions, then recombining the solids for the two hour "baking" period.

The denitration results are shown in Table 2. About 900 grams of off-gas are evolved per liter of waste. The off-gas consists of acidic water vapor and oxides of nitrogen $\left(\mathrm{NO}_{x}\right)$, giving the off-gas a brown color. The solid product is metal oxides and silicates of previously dissolved solids.

The denitrated $\mathrm{Na} L L W$ is dark brown in color and forms relatively hard clinkers, which may need to be ground. For Na LLW denitrated without additives, X-ray diffraction results (Table 3) indicate that sodium nitrate is the major remaining component. The density of this material is $0.96 \mathrm{~g} / \mathrm{cm}^{3}$. Only $68.9 \%$ of the nitrates are destroyed when denitrated without additives, which accounts for the remaining sodium nitrate. When clay is added, silicon oxide and nepheline, a sodium-aluminum silicate, are the major components produced. With clay, which consists of aluminum oxide and silicon oxide, nitrate destruction is $97.8 \%$ effective and the desired mineral is formed. The density is $0.67 \mathrm{~g} / \mathrm{cm}^{3}$ with the clay. Grouting studies have shown that either solid product, with or without clay, can be successfully grouted. A volume reduction of 3.4 is achieved, indicating 3.4 cubic meters of liquid waste would result in only one cubic meter of grout. It is thought that the remaining amount of nitrates could be tolerated by Portland cement; therefore, the addition of clay may not be necessary. Nitrate leach tests are needed to confirm this conclusion.

Over $99 \%$ of the nitrates are destroyed with or without the addition of clay for Al LLW; therefore, the clay is not needed. This improves the volume reduction and avoids sending unnecessary additives to storage. The denitrated product is a very light tan and is relatively soft, similar to powdered milk. Its density is $0.64 \mathrm{~g} / \mathrm{cm}^{3}$. X-ray diffraction shows that amorphous material is the major component of denitrated Al LLW without additives. This is probably an amorphous form of aluminum oxide. When clay is added, 
Table 2. Denitration results per liter of waste $\left(650^{\circ} \mathrm{C}\right.$ for 2 hours).

\begin{tabular}{lcccrrr}
\hline & $\begin{array}{c}\text { Na LLW } \\
\text { w/o clay } \\
(\mathrm{g})\end{array}$ & $\begin{array}{c}\text { Na LLW } \\
\text { with clay } \\
(\mathrm{g})\end{array}$ & $\begin{array}{c}\text { Al LLW } \\
\text { w/o clay } \\
(\mathrm{g})\end{array}$ & $\begin{array}{c}\text { Al LLW } \\
\text { with clay } \\
(\mathrm{g})\end{array}$ & $\begin{array}{c}\text { Zr LLW } \\
\text { w/o clay } \\
(\mathrm{g})\end{array}$ & $\begin{array}{c}\text { Zr LLW } \\
\text { with clay }\end{array}$ \\
\hline Total Mass & 1139.2 & 1139.2 & 1108.4 & 1108.4 & 1119.8 & 1119.8 \\
Initial Dissolved Solids & 230.9 & 230.9 & 188.8 & 188.8 & 241.3 & 214.3 \\
Clay & & 137.7 & & 9.4 & & 13.0 \\
Theoretical Product & 60.5 & 60.5 & 22.7 & 22.7 & 46.0 & 46.0 \\
Actual Product & 118.0 & 185.9 & 23.1 & 31.3 & 47.2 & 57.8 \\
Waste in Product & 118.0 & 64.6 & 23.1 & 22.9 & 47.2 & 47.2 \\
Acidic Water Vapor & 908.3 & 922.7 & 919.6 & 920.6 & 905.5 & 906.9 \\
and Other Volatiles & & & & & & \\
Initial NO & 184.7 & 184.7 & 174.3 & 174.3 & 170.6 & 170.6 \\
NO $_{x}$ Evolved & 127.2 & 180.6 & 173.9 & 174.1 & 169.4 & 169.4 \\
\% Denitration & $68.9 \%$ & $97.8 \%$ & $99.8 \%$ & $99.9 \%$ & $99.3 \%$ & $99.3 \%$ \\
\hline
\end{tabular}

Table 3. X-ray diffraction results for denitrated solids.

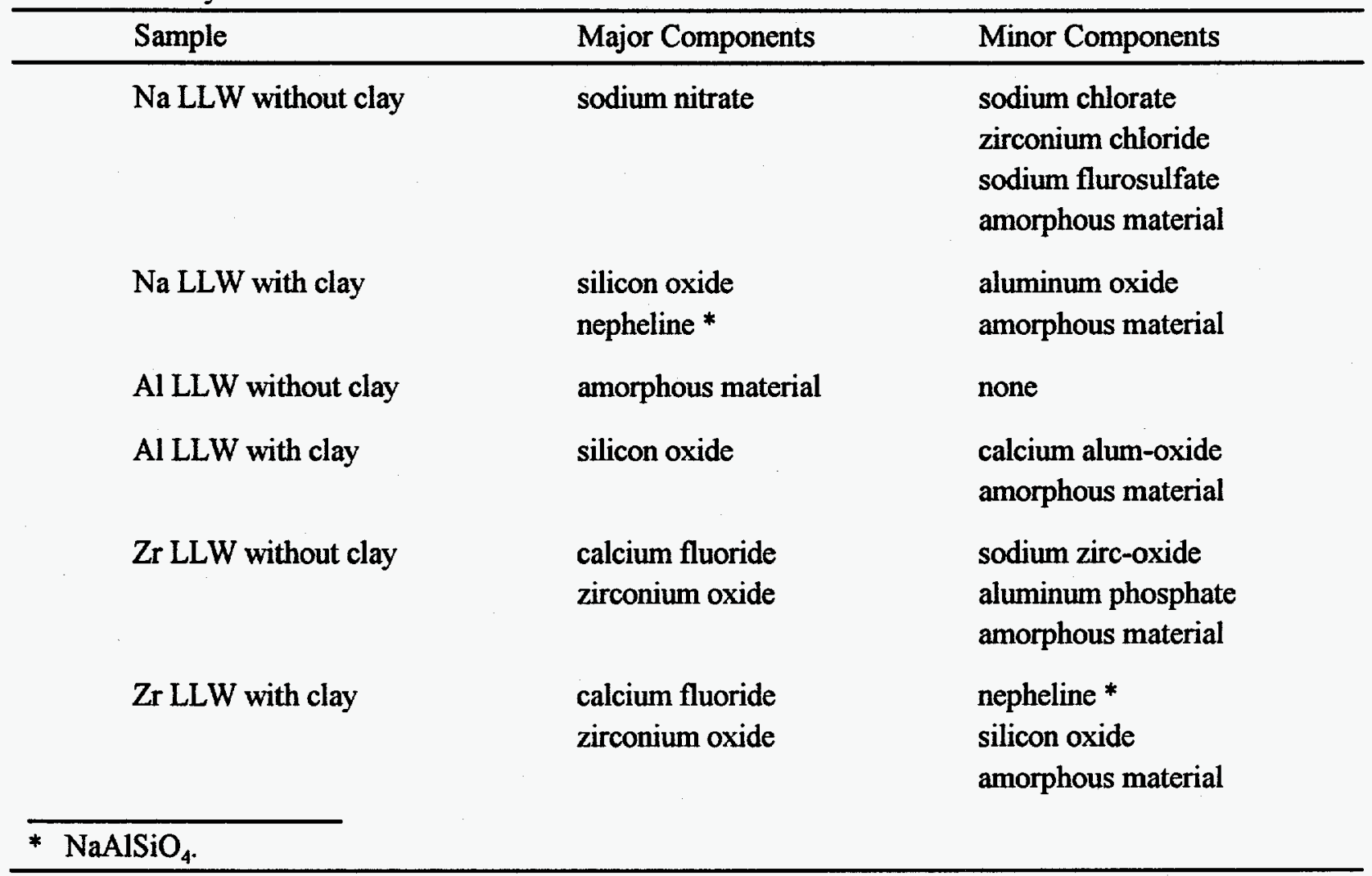


silicon oxide is the major component and calcium-aluminum oxide is a minor component. The waste volume is reduced by eight times when the Al LLW product is grouted. This means eight cubic meters of liquid waste can be stored as one cubic meter of grout.

The $\mathrm{Zr}$ LLW also results in over $99 \%$ nitrate destruction with or without clay. The denitrated solid is a creamy white color, similar to powdered milk, and has a density of $0.45 \mathrm{~g} / \mathrm{cm}^{3}$ without clay. For either version, calcium fluoride and zirconium oxide are the major components of the product. A volume reduction of eight is also achievable for $\mathrm{Zr} \mathrm{LLW}$.

\section{GROUT PREPARATION, CURING, AND COMPRESSIVE STRENGTH}

When the denitrated LLW is added to water, the $\mathrm{pH}$ of the solution is extremely basic $(\mathrm{pH}>13)$. When the waste is added to ordinary Portland cement, the cement gel $\mathrm{pH}$ is increased above the optimum $\mathrm{pH}$ $(\approx 9)$ at which the hydration reactions occur. Therefore, $\mathrm{pH}$ modifiers must be added to mitigate the highly alkaline denitrated wastes. The Pennsylvania State University Materials Testing Laboratory recommended a grout formulation of $1 / 3$ Portland cement, $1 / 3$ blast furnace slag, and $1 / 3$ silica fume. ${ }^{15}$ This produced a very pasty mix; thus, Class F fly ash was substituted for silica fume to achieve a grout that could be poured.

For $\mathrm{Na}$ LLW without additives, waste loadings of $15 \%$ to $35 \%$ were studied while waste loadings of $15 \%$ to $25 \%$ were studied for Na LLW denitrated with clay. Waste loadings from $10 \%$ to $35 \%$ in $5 \%$ increments were studied for $\mathrm{Al}$ and $\mathrm{Zr} \mathrm{LLW}$. Grout mix properties were qualitatively noted for ease of mixing and pouring. Grout specimens were prepared in $2 \times 2 \times 2$ inch molds as required by ASTM C109-93, Standard Test Method for Compressive Strength of Hydraulic Mortars (Using 2-in. or 50-mm Cube Specimens). ${ }^{16,17}$ Since cube specimens were prepared individually, mixing was done by hand for the small batches.

A super-plasticizer is added to the mix to improve fluid properties of the wet grout. One-half milliliter is added per cube batch, which is equivalent to 20 ounces per 100 pounds of Portland cement. In general, for waste loadings from $10 \%$ to $25 \%$, the grout is fluid and can be poured into the molds. For waste loadings of $30 \%$ to $35 \%$, the grout has a lower slump (piles up in the mold rather than leveling off). If higher waste loadings are pursued, this problem may be resolved by vibrating the mold or drum to cause the grout to settle.

Three types of curing were tested: (1) natural curing for 28 days in a closed plastic bag to simulate capped storage drum conditions, (2) natural curing for 28 days over a water bath to simulant moist, humid conditions, and (3) fast curing at elevated temperature and pressure in an autoclave at $200^{\circ} \mathrm{C}$ and $200 \mathrm{psi}$ for 2 hours. The latter method is called FUETAP for formed under elevated temperature and pressure. ${ }^{18}$

The cured specimens were tested for compressive strength (ASTM C109-93) on a Tinius-Olson Super $\mathrm{L}$ analyzer which determines the peak force the cube can withstand. This resultant force is divided by the area to which the force is applied (in most cases this is 4 square inches). Compressive strength is reported in units of pounds per square inch (psi) rounded to the nearest 10. The compressive strength of grout samples must be greater than 500 psi. $^{9}$ 
The curing method did have an effect on the subsequent density and compressive strength as noted in Tables 4 to 7 . The results clearly show that the cubes cured in closed plastic bags have higher compressive strengths. The improved strength is sustained over a broader range of waste loading. The cubes cured in the humid enclosure and the plastic bags have similar densities; however, the density of the autoclaved cubes is much lower.

There does not appear to be a correlation between waste loading and density. However, compressive strength decreases as waste loading increases. The latter may be more a function of the amount of water added to make the mixed grout more flowable.

The volume reduction factors noted in the above tables indicate the change in volume from the original liquid LLW to the solid grout waste form. For example, a volume reduction factor of six would mean that six cubic meters of liquid LLW would yield one cubic meter of waste grout following denitration and grouting. The volume reduction factors are derived experimentally from the simulated waste and grout. The volume reduction is directly related to the denitration process. The "Remaining Waste" on Table 2 shows that $\mathrm{Al} \mathrm{LLW}$ has only 23 grams remaining while $\mathrm{Zr} \mathrm{LLW}$ has 47 grams. Thus, the Al LLW volume reduction factors in Table 6 are about twice those of the $\mathrm{Zr}$ LLW noted in Table 7.

A word of caution concerning the volume reduction factors is that these factors are for the low-level waste stream only. In taking the original calcine from "cradle to grave" there is actually a volume increase. This occurs in the separation process where dilutions are made when nitric acid is added to dissolve the calcine and when other solvents or water are added in the extraction processes. For example, based on January 24, 1996 flowsheets, 1 kilogram of Al calcine has a volume of 0.9 liters. Following the separation processes, a total of 45.6 cubic meters of LLW are produced. If the Al LLW is denitrated and grouted at $15 \%$ waste loading and the LLW volume is reduced by a factor of 8.5 (Table 6), 5.4 cubic meters (45.6/8.5) of grout would be produced. Thus, the overall volume change from $\mathrm{Al}$ calcine to $\mathrm{Al}$ grout is an increase from 0.9 to 5.4 liters. For $\mathrm{Zr}$ calcine, the overall volume change is not as dramatic as 1 liter of $\mathrm{Zr}$ calcine yields 3.5 liters of LLW grout at $30 \%$ waste loading. The liquid sodium-bearing waste, however, does reduce the volume from 1 liter to 0.6 liters of $\mathrm{Na}$ LLW grout.

\section{LEACH RESULTS}

Following strength testing, the grout cubes were submitted for leach testing to determine the amount of hazardous metals that may leach from the grout. This is completed using the U.S. Environmental Protection Agency's Toxicity Characteristic Leaching Procedure (TCLP) ${ }^{19}$ For the grout to pass TCLP, the resulting leach values must be less than the regulatory levels specified in 40 CFR 261.24, Table 1 , "Maximum Concentration of Contaminants for the Toxicity Characteristic." The TCLP results are presented in Table 8 for the various LLW streams tested to date. A sample of Portland cement was leached for reference. 
Table 4. Grout density and compressive strength as a function of waste loading and curing method for sodium-bearing LLW denitrated without additives.

\begin{tabular}{|c|c|c|c|c|c|c|c|}
\hline \multicolumn{2}{|c|}{ Nat LLW (w/o clay) } & \multicolumn{2}{|c|}{ Humid Cured } & \multicolumn{2}{|c|}{ Enclosed Cured } & \multicolumn{2}{|c|}{ Autoclv. Cured } \\
\hline $\begin{array}{c}\text { Waste } \\
\text { Loading }\end{array}$ & $\begin{array}{l}\text { Volume } \\
\text { Reduct. }\end{array}$ & $\begin{array}{l}\text { Density } \\
\left(\mathrm{g} / \mathrm{cm}^{3}\right)\end{array}$ & $\begin{array}{c}\text { Comp. Str. } \\
\text { (psi) }\end{array}$ & $\begin{array}{l}\text { Density } \\
\left(\mathrm{g} / \mathrm{cm}^{3}\right)\end{array}$ & $\begin{array}{c}\text { Comp. Str. } \\
\text { (psi) }\end{array}$ & $\begin{array}{l}\text { Density } \\
\left(\mathrm{g} / \mathrm{cm}^{3}\right)\end{array}$ & $\begin{array}{c}\text { Comp. Str. } \\
\text { (psi) }\end{array}$ \\
\hline $15 \%$ & 1.6 & na & na & 1.82 & 3170 & na & na \\
\hline $20 \%$ & 2.1 & na & na & 1.80 & 3000 & na & na \\
\hline $25 \%$ & 2.7 & na & na & 1.80 & 2830 & 1.40 & 2450 \\
\hline $30 \%$ & 3.3 & 1.78 & 1970 & 1.80 & 2750 & 1.36 & 1850 \\
\hline $35 \%$ & 3.8 & 1.80 & 1850 & 1.82 & 2440 & 1.32 & 1260 \\
\hline
\end{tabular}

Table 5. Grout density and compressive strength as a function of waste loading and curing method for sodium-bearing LLW denitrated with clay.

\begin{tabular}{|c|c|c|c|c|c|c|c|}
\hline \multicolumn{2}{|c|}{ Nal LLW (with clay) } & \multicolumn{2}{|c|}{ Humid Cured } & \multicolumn{2}{|c|}{ Enclosed Cured } & \multicolumn{2}{|c|}{ Autoclv. Cured } \\
\hline $\begin{array}{l}\text { Waste } \\
\text { Loading }\end{array}$ & $\begin{array}{l}\text { Volume } \\
\text { Reduct. }\end{array}$ & $\begin{array}{r}\text { Density } \\
\left(\mathrm{g} / \mathrm{cm}^{3}\right) \\
\end{array}$ & $\begin{array}{c}\text { Comp. Str. } \\
\text { (psi) }\end{array}$ & $\begin{array}{l}\text { Density } \\
\left(\mathrm{g} / \mathrm{cm}^{3}\right)\end{array}$ & $\begin{array}{c}\text { Comp. Str. } \\
\text { (psi) }\end{array}$ & $\begin{array}{l}\text { Density } \\
\left(\mathrm{g} / \mathrm{cm}^{3}\right) \\
\end{array}$ & $\begin{array}{c}\text { Comp. Str. } \\
\text { (psi) }\end{array}$ \\
\hline $15 \%$ & 2.3 & 1.69 & 2340 & 1.61 & 3150 & 1.27 & 2380 \\
\hline $20 \%$ & 3.2 & 1.69 & 2830 & 1.69 & 3140 & 1.17 & 1860 \\
\hline $25 \%$ & 3.9 & 1.60 & 100 & 1.59 & 1650 & 1.10 & 1040 \\
\hline
\end{tabular}

Table 6. Grout density and compressive strength as a function of waste loading and curing method for LLW derived from aluminum calcine.

\begin{tabular}{|c|c|c|c|c|c|c|c|}
\hline \multicolumn{2}{|c|}{ Al LLW } & \multicolumn{2}{|c|}{ Humid Cured } & \multicolumn{2}{|c|}{ Enclosed Cured } & \multicolumn{2}{|c|}{ Autoclv. Cured } \\
\hline $\begin{array}{c}\text { Waste } \\
\text { Loading } \\
\end{array}$ & $\begin{array}{l}\text { Volume } \\
\text { Reduct. }\end{array}$ & $\begin{array}{l}\text { Density } \\
\left(\mathrm{g} / \mathrm{cm}^{3}\right) \\
\end{array}$ & $\begin{array}{c}\text { Comp. Str. } \\
\text { (psi) }\end{array}$ & $\begin{array}{l}\text { Density } \\
\left(\mathrm{g} / \mathrm{cm}^{3}\right)\end{array}$ & $\begin{array}{c}\text { Comp. Str. } \\
\text { (psi) }\end{array}$ & $\begin{array}{l}\text { Density } \\
\left(\mathrm{g} / \mathrm{cm}^{3}\right)\end{array}$ & $\begin{array}{c}\text { Comp. Str. } \\
\text { (psi) }\end{array}$ \\
\hline $110 \%$ & 5.5 & 1.81 & 4070 & 1.79 & 4040 & 1.39 & 470 \\
\hline $15 \%$ & 8.5 & 1.84 & 2860 & 1.79 & 4350 & 1.44 & 1590 \\
\hline $20 \%$ & 11.0 & 1.75 & 1880 & 1.78 & 3450 & 1.48 & 2030 \\
\hline $25 \%$ & 13.6 & 1.82 & 2240 & 1.76 & 2610 & 1.46 & 1760 \\
\hline $30 \%$ & 16.2 & 1.81 & 1840 & 1.74 & 2360 & 1.46 & 1710 \\
\hline $35 \%$ & 20.1 & 1.67 & 310 & 1.71 & 2170 & 1.38 & 1050 \\
\hline
\end{tabular}


Table 7. Grout density and compressive strength as a function of waste loading and curing method for LLW derived from zirconium calcine.

\begin{tabular}{|c|c|c|c|c|c|c|c|}
\hline \multicolumn{2}{|c|}{ Zr LLW } & \multicolumn{2}{|c|}{ Humid Cured } & \multicolumn{2}{|c|}{ Enclosed Cured } & \multicolumn{2}{|c|}{ Autoclv. Cured } \\
\hline $\begin{array}{c}\text { Waste } \\
\text { Loading }\end{array}$ & $\begin{array}{l}\text { Volume } \\
\text { Reduct. }\end{array}$ & $\begin{array}{l}\text { Density } \\
\left(\mathrm{g} / \mathrm{cm}^{3}\right)\end{array}$ & $\begin{array}{l}\text { Comp. Str. } \\
\text { (psi) }\end{array}$ & $\begin{array}{l}\text { Density } \\
\left(\mathrm{g} / \mathrm{cm}^{3}\right) \\
\end{array}$ & $\begin{array}{c}\text { Comp. Str. } \\
\text { (psi) }\end{array}$ & $\begin{array}{l}\text { Density } \\
\left(\mathrm{g} / \mathrm{cm}^{3}\right) \\
\end{array}$ & $\begin{array}{c}\text { Comp. Str. } \\
\text { (psi) }\end{array}$ \\
\hline $10 \%$ & 2.7 & $\mathbf{n} / \mathbf{a}$ & $\mathbf{n} / \mathbf{a}$ & 1.81 & 4920 & 1.59 & 3860 \\
\hline $15 \%$ & 4.1 & 1.81 & 3810 & 1.82 & 4800 & 1.50 & 2400 \\
\hline $20 \%$ & 5.5 & 1.77 & 2240 & 1.81 & 3520 & 1.53 & 1840 \\
\hline $25 \%$ & 6.9 & 1.83 & 2450 & 1.84 & 3930 & 1.44 & 1830 \\
\hline $30 \%$ & 8.3 & 1.97 & 3550 & 1.84 & 3570 & 1.56 & 1290 \\
\hline $35 \%$ & 9.6 & 1.81 & 2410 & 1.83 & 3430 & 1.53 & 1150 \\
\hline
\end{tabular}

Table 8. Leach results.

\begin{tabular}{|c|c|c|c|c|c|}
\hline $\begin{array}{c}\text { Grout } \\
\text { Sample }\end{array}$ & $\begin{array}{c}\text { Waste } \\
\text { Loading } \\
\%\end{array}$ & $\begin{array}{c}\mathrm{Hg} \\
0.2 \mathrm{mg} / \mathrm{L} \\
\max .\end{array}$ & $\begin{array}{c}\mathrm{Pb} \\
5 \mathrm{mg} / \mathrm{L} \\
\max \end{array}$ & $\begin{array}{c}\mathrm{Cd} \\
1 \mathrm{mg} / \mathrm{L} \\
\max \end{array}$ & $\begin{array}{c}\mathrm{Cr} \\
5 \mathrm{mg} / \mathrm{L} \\
\max .\end{array}$ \\
\hline Portland cement & 0 & $<0.005$ & $<0.060$ & $<0.004$ & $<0.006$ \\
\hline \multirow{3}{*}{$\begin{array}{l}\mathrm{Na} \text { LLW at } 650^{\circ} \mathrm{C} \\
\text { grouted with } 3 \text {-way } \\
\text { blend (no clay) }\end{array}$} & 25 & $<0.005$ & $<0.060$ & $<0.004$ & 0.022 \\
\hline & 30 & $<0.005$ & $<0.060$ & $<0.004$ & 0.028 \\
\hline & 35 & $<0.005$ & $<0.060$ & $<0.004$ & 0.067 \\
\hline \multirow{3}{*}{$\begin{array}{l}\mathrm{Na} \text { LLW + Clay at } \\
650^{\circ} \mathrm{C} \text { grouted with } \\
\text { cement only }\end{array}$} & 15 & * & $<0.033$ & 0.0056 & 1.80 \\
\hline & 20 & * & $<0.033$ & 0.0057 & 3.51 \\
\hline & 25 & * & $<0.033$ & 0.0066 & 6.14 \\
\hline \multirow{3}{*}{$\begin{array}{l}\mathrm{Na} \text { LLW + Clay } \\
\text { at } 650^{\circ} \mathrm{C} \text { grouted } \\
\text { with cement and } \\
\text { slag }\end{array}$} & 15 & * & $<0.033$ & 0.0182 & 0.1816 \\
\hline & 20 & * & $<0.033$ & 0.0841 & 0.6189 \\
\hline & 25 & * & $<0.033$ & 0.1230 & 3.136 \\
\hline $\mathrm{Al} \mathrm{LLW}$ at $650^{\circ} \mathrm{C}$ & 10 to 35 & $* *$ & ** & ** & $* *$ \\
\hline $\mathrm{Zr} \mathrm{LLW}$ at $650^{\circ} \mathrm{C}$ & 10 & ** & ** & $<0.0030$ & $* *$ \\
\hline grouted with 3-way & 15 & ** & $* *$ & 0.0080 & ** \\
\hline \multirow[t]{4}{*}{ blend } & 20 & $* *$ & $* *$ & 0.0183 & $* *$ \\
\hline & 25 & $* *$ & $* *$ & $<0.0030$ & $* *$ \\
\hline & 30 & ** & ** & 0.0893 & ** \\
\hline & 35 & $* *$ & $* *$ & 0.2621 & $* *$ \\
\hline \multicolumn{6}{|c|}{ * Sample not analyzed for component } \\
\hline
\end{tabular}


The TCLP is a rather aggressive leaching procedure. Each grout sample (up to 100 grams) is crushed to a minimum sieve size of 9.4 millimeter. Because the samples are basic, the procedure requires that a solution of acetic acid as the extraction fluid. The solid phase is extracted with an amount of extraction fluid equal to 20 times the weight of the solid phase. The sample and extraction fluid are agitated together by rotating the extraction vessel in an end-over-end manner at 30 revolutions per minute for 18 hours. The extraction fluid is then submitted for analysis of cadmium, chromium, lead, and mercury. The $40 \mathrm{CFR}$ Section 261.24 limit for chromium and lead is 5.0 milligram per liter $(\mathrm{mg} / \mathrm{L})$. The limit for cadmium is $1.0 \mathrm{mg} / \mathrm{L}$ and the limit for mercury is $0.2 \mathrm{mg} / \mathrm{L}$.

Three types of Na LLW grout cubes were leach tested: (1) Na LLW denitrated without additives, (2) $\mathrm{Na} \mathrm{LLW} \mathrm{denitrated} \mathrm{with} \mathrm{clay} \mathrm{and} \mathrm{grouted} \mathrm{with} \mathrm{Portland} \mathrm{cement,} \mathrm{and} \mathrm{(3)} \mathrm{Na} \mathrm{LLW}$ denitrated with clay and grouted with Portland cement and blast furnace slag. Past research and these data show that lead and mercury are usually below detectable limits. These elements are either well contained in the cement matrix or are driven off during the denitration process. ${ }^{20}$ An elemental material balance is needed to determine their disposition. For the $\mathrm{Na}$ LLW denitrated without additives, lead, mercury, and cadmium are below detection limits and chromium leaches well below regulatory limits.

When Na LLW is denitrated with clay and grouted with Portland cement, chromium leaches at much higher levels. At $25 \%$ waste loading, the chromium leach is above the regulatory limit of 5 milligrams per liter. Thermal denitration oxidizes chromium to the +6 oxidation state and the sulfur in the blast furnace slag reduces it to an oxidation state of $+3 .^{21-23}$ The +3 chromium does not leach as much at the +6 . Thus, slag was added to later grout mixes as shown in the third $\mathrm{Na}$ LLW set. The slag reduced the chromium leach levells below regulatory limits. These leach results show that the addition of clay is not an advantage over the waste processed without additives. The denitration results indicate that the clay aids in nitrate destruction for $\mathrm{Na} \mathrm{LLW}$, but then requires slag in the grout to avoid chromium leach problems. Therefore, clay addition is not recommended; however, nitrate leach studies are needed to confirm this recommendation.

The Al LLW does not contain any hazardous components and the Zr LLW only contains cadmium. The cadmium leaches below the regulatory limit for all $\mathrm{Zr}$ LLW waste loadings. The Zr LLW is 10 times below the limit at $30 \%$ waste loading. For this particular sample, 34.24 grams were leached, which contained a total of 274 milligrams cadmium and the leachant volume was 685 milliliters. The results from Table 8 show 0.0893 micrograms per milliliter leached for a total of 0.061 milligrams cadmium. Thus, only $0.03 \%$ of the cadmium leached out of the Zr LLW grout cube.

\section{CONCLUSIONS AND RECOMMENDED FORMULATIONS}

The projected low-level wastes derived from liquid sodium-bearing waste and from aluminum and zirconium calcines can be successfully grouted using denitration and a blended grout based on these laboratory tests. Thermal denitration is effective in destroying the nitrates and provides a solid product that is compatible with Portland cement grout. Denitration reduces the waste volume, which should result in lower disposal costs. However, denitration of sodium-bearing waste may cause other heavy metals to volatilize in addition to mercury. If so, the off-gas system design may be significantly impacted.

The three-way blend of Portland cement, blast furnace slag, and fly ash is recommended for ICPP low-level wastes. Waste loadings up to $35 \%$ produced acceptable compressive strengths and leach 
resistances. The leach rate of chromium can be controlled by using blast furnace slag in the grout. The higher loadings produce thicker grouts; therefore, a maximum of $25 \%$ to $30 \%$ waste loading is recommended to provide good fluid properties, such that the grout can be poured from the mixer into the storage drums. Natural curing in closed storage drums is recommended based on higher compressive strength results.

\section{FUTURE STUDIES / ISSUES}

These Na LLW studies are based on a flowsheet where the liquid sodium-bearing waste is separated directly into high-activity and low-level wastes. However, there are plans to calcine much of the sodiumbearing waste. Therefore, new Na LLW grout studies are needed for LLW derived from calcined sodiumbearing waste. If the liquid sodium-bearing waste flowsheet is pursued, then nitrate leach studies will be needed to confirm the non-use of clay addition. Also grout testing is needed for liquid LLW from decontamination and process equipment waste. Waste form qualification testing for all LLW streams must continue to meet compressive strength requirements following immersion for 90 days and thermal cycling.

Continued laboratory studies are recommended to develop a material and energy balance for the denitration and grouting processes. Knowledge of the disposition of each component/element in the waste is needed. For example, mercury and lead do not show up on leach tests. One study indicates that cadmium nitrate and lead nitrate volatilize during incineration. ${ }^{20}$ Mercury volatilization is accounted for in the off-gas design; however, if other heavy metals volatilize, it must be determined whether they can be captured and treated. Also, an energy balance for the denitration, grouting, and curing processes is needed to determine overall costs and where heat could be recovered and recycled.

If the denitration process is run full-scale, up to 500 gallons of liquid Al LLW could be processed and grouted in a single 55-gallon drum. This efficient volume reduction may have a penalty in off-gas produced. The 500 gallons of liquid waste would result in approximately 720 pounds of $\mathrm{NO}_{\mathrm{x}}$ and 3800 pounds of acidic water vapor. This amount of $\mathrm{NO}_{\mathrm{x}}$ would need to be released over a period of two hours to remain below the current release limits of 472 pounds per hour. Thus, only 10 to 12 drums a day could be produced, but this would represent 5000 to 6000 gallons of waste treated per day.

To become a viable process, denitration equipment must be located and tested, as well as materials of construction that can withstand the corrosive off-gas. The need to grind the solidified LLW will be studied in the pilot plant, as well as the ability to denitrate continuously rather than batch-wise. Further, the grout waste forms must be extensively qualified as to toxic chemical leach resistance and compressive strength following curing, immersing, and thermal cycling. Failure of any one of these tests or lack of equipment may require a whole new process to precondition the waste for grouting. Nevertheless, current grout tests are acceptable using thermal denitration and designers recommend a rotary kiln or twin-screw dryer for pilot-plant tests. ${ }^{24}$

The grout mixing and fluid properties should be revisited during the pilot-scale tests. To avoid excessive hands-on operation and maintenance, the grout needs to flow easily from the mixer to the storage drum. An alternative is in-drum mixing where higher waste loadings could be tested. In this case the thicker grouts can be mixed in the drum without the need for pouring. Qualification tests must be performed on fullscale disposal drums of grouted LLW. 


\section{REFERENCES}

1. Lockheed Martin Idaho Technologies Co., High-Level Waste Program Plan, INEL-96/122, April 1996.

2. R. S. Herbst, et al., Experimental Results: Pilot Plant Calcine Dissolution and Liquid Feed Stability, INEL-95/0097, February 1995.

3. J. Howard Kittel, editor, "Near-Surface Land Disposal," Radioactive Waste Management Handbook, Volume 1, Harwood Academic Publishers, New York, NY, 1989.

4. Frank H. Huang, et al., "Low-Level Radioactive Hanford Wastes Immobilized by Cement-Based Grouts," Nuclear Technology, Vol. 107, September 1994, pp. 254-270.

5. International Atomic Energy Agency, Improved Cement Solidification of Low and Intermediate Level Radioactive Wastes, Technical Report Series No 350, International Atomic Energy Agency, Vienna, 1993.

6. M. Atkins and F. P Glasser, "Application of Portland Cement-Based Materials to Radioactive Waste Immobilization," Waste Management, Vol. 12, 1992, pp. 105-131.

7. Keiji Miyamoto, et al., "Three Year Experimental Study of Leaching Phenomena from Low Level Radioactive Homogeneous Cement-Based Waste Forms," Journal of Nuclear Science and Technology, Vol. 30, No. 7, July 1993, pp. 70-81.

8. Wayne S. Adaska, Stewart W. Tresouthick, and Presbury B. West, Solidification and Stabilization of Wastes Using Portland Cement, Portland Cement Association, Skokie, IL, 1991.

9. U.S. Nuclear Regulatory Commission Technical Branch of the Low-Level Waste Management and Decommissioning Division, "Technical Position on Waste Form," Revision 1, January, 1991.

10. A. K. Herbst, letter to D. V. Croson, "Experimental Test Plan for Sodium-Bearing Waste Stabilization/Solidification Using Portland and High-Alumina Cements, Revision \#1," Lockheed Martin Idaho Technologies Co., Idaho Falls, ID, AKH-1 1-94, October 10, 1994.

11. M. Atkins, F. P. Glasser, and J. J. Jack, "Zeolite P in Cements: Its Potential for Immobilizing Toxic and Radioactive Waste Species," Waste Management, Vol. 15, No.2, 1995, pp. 127-135.

12. A. R. Brough, et al., "Microstructural Aspects of Zeolite Formation in Alkali Activated Cements Containing High Levels of Fly Ash," Material Research Society Symposium Proceedings, 1995, Vol. 370, pp. 199-208.

13. Judith L. Larosa, Stephen Kwan, and Michael W. Grutzeck, "Self-Generating Zeolite-Cement Composites," Material Research Society Symposium Proceedings, 1992, Vol. 245, pp. 211-216. 
14. J. A. Nenni, letter to D. V. Croson, "Status of Alternative Calcination Development Laboratory Tests," Lockheed Martin Idaho Technologies Co., Idaho Falls, ID, JAN-05-95, December 21, 1995.

15. B. E. Scheetz, unpublished research, Materials Research Laboratory, Pennsylvania State University, University Park, PA, 1994.

16. ASTM C192-90a, "Standard Practice for Making and Curing Concrete Test Specimens in the Laboratory," American Society for Testing and Materials, April 27, 1990.

17. ASTM C109-93,"Standard Test Method for Compressive Strength of Hydraulic Cement Mortars (Using 2-in. or 50-mm Cube Specimens)," American Society for Testing and Materials, August 15, 1993.

18. L. R. Dole, et al., "Cementitious Radioactive Waste Hosts Formed Under Elevated Temperature and Pressures (FUETAP Concretes)," Symposium on the Scientific Basis for Nuclear Waste Management, Oak Ridge National Laboratory, Oak Ridge, TN, presented at the Boston, MA, November 16-19, 1981.

19. U. S. Environmental Protection Agency, "Method 1311, Toxicity Characteristic Leaching Procedure," Revision 0, July 1992.

20. T. C. Ho, H. W. Chu, and J. R. Hopper, "Metal Volatilization and Separation During Incineration," Waste Management, Vol. 13, 1993, pp. 455-466.

21. C. A. Langton and P. B. Wong, "Properties of Slag Concrete for Low-Level Waste Containment," Ceramic Transactions, Nuclear Waste Management IV, The American Ceramic Society, 1991, pp. 191-199.

22. A. Kindness, et al., "Immobilization of Chromium in Cement Matrices," Waste Management, Vol. 14, No. 1, 1994, pp. 3-11.

23. M. L. Allan and L. E. Kukacka, "Blast Furnace Slag-Modified Grouts For In Situ Stabilization of Chromium-Contaminated Soil," Waste Management, Vol. 15, No. 3, 1995, pp. 193-202.

24. B. K. Hampton, Low Level Waste Grout Pilot Plant Conceptual Design Report, Delivery Order 94-08, September, 1994, Flour Daniel, Inc., Irvine, CA. 